\title{
Variability of risk factors and diabetes complications
}

\author{
Antonio Ceriello* and Francesco Prattichizzo *(1)
}

\begin{abstract}
Several studies suggest that, together with glucose variability, the variability of other risk factors, as blood pressure, plasma lipids, heart rate, body weight, and serum uric acid, might play a role in the development of diabetes complications. Moreover, the variability of each risk factor, when contemporarily present, may have additive effects. However, the question is whether variability is causal or a marker. Evidence shows that the quality of care and the attainment of the target impact on the variability of all risk factors. On the other hand, for some of them causality may be considered. Although specific studies are still lacking, it should be useful checking the variability of a risk factor, together with its magnitude out of the normal range, in clinical practice. This can lead to an improvement of the quality of care, which, in turn, could further hesitate in an improvement of risk factors variability.
\end{abstract}

Keywords: Diabetes mellitus, Glucose variability, Blood pressure variability, Lipids variability, Body weight variability, Uric acid variability, Heart rate variability, Oxidative stress, Cardiovascular complications, Microvascular complications

\section{Background}

Growing attention has been recently paid to the possible the role of glucose variability (GV) in the development of diabetic complications, particularly cardiovascular $(\mathrm{CV})$ ones [1].

Many observational [1] and some interventional studies [2], as well as post-hoc analyses of trials such as the "Action in Diabetes and Vascular Disease: Preterax and Diamicron MR Controlled Evaluation" (ADVANCE), [3] the "Trial Comparing Cardiovascular Safety of Insulin Degludec vs. Insulin Glargine in Patients With Type 2 Diabetes at High Risk of Cardiovascular Events" (DEVOTE), [4] the "Veterans Affairs Diabetes Trial" (VADT), [5] the "Antihypertensive and Lipid-Lowering Treatment to Prevent Heart Attack Trial" (HALLHAT), [6] the "Action to Control Cardiovascular Risk in Diabetes" (ACCORD) trial, [7] and the "Empagliflozin Cardiovascular Outcome Event (EMPA-REG OUTCOME) trial

\footnotetext{
*Correspondence: antonio.ceriello@hotmail.it; francesco. prattichizzo@multimedica.it

IRCCS MultiMedica, Via Gaudenzio Fantoli, 16/15, 20138 Milan, Italy
}

[8] confirm that in type 2 diabetes (T2D) long-term GV is correlated with an increased risk of both CV and microvascular complications. However, we need to underline that while we pay much attention to GV, [1] emerging evidence suggests that also the long-term variability of other risk factors may be involved in the development of diabetes complications.

Long-term variability is defined as the fluctuations of a certain risk factor outside the recommended range in successive measures [1]. While a number of metrics has been proposed to assess long-term variability, the most commonly used is the standard deviation (SD) of the collected values [1].

Common risk factors for the development of diabetes complications include blood pressure, lipid parameters (i.e. total, HDL-, and LDL-cholesterol and triglycerides), heart rate, body weight, and uric acid. Here we summarize the key available literature describing the variability of such risk factors in relation to the development of complications in patients with diabetes. Then, we synthesize the therapeutic options that seem available at the moment to face this new emerging challenge of diabetes management.

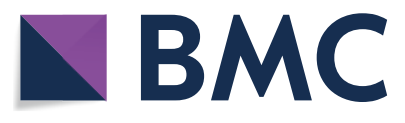

(c) The Author(s) 2021. This article is licensed under a Creative Commons Attribution 4.0 International License, which permits use, sharing, adaptation, distribution and reproduction in any medium or format, as long as you give appropriate credit to the original author(s) and the source, provide a link to the Creative Commons licence, and indicate if changes were made. The images or other third party material in this article are included in the article's Creative Commons licence, unless indicated otherwise in a credit line to the material. If material is not included in the article's Creative Commons licence and your intended use is not permitted by statutory regulation or exceeds the permitted use, you will need to obtain permission directly from the copyright holder. To view a copy of this licence, visit http://creativeco mmons.org/licenses/by/4.0/. The Creative Commons Public Domain Dedication waiver (http://creativecommons.org/publicdomain/ zero/1.0/) applies to the data made available in this article, unless otherwise stated in a credit line to the data. 


\section{Variability of risk factors and diabetic complications Blood pressure}

Grove et al. [9] originally observed variability in visit-tovisit systolic blood pressure (SBP) was related to incidence of coronary heart disease in a population with or without hypertension.

Several studies, after this finding, have reported that a blood pressure (both systolic and diastolic) variability in people with diabetes is an independent predictor of both macro- and microvascular complications, particularly nephropathy.

The ADVANCE was a factorial randomized controlled trial to test the effect of a tight control of both glucose and blood pressure in patients with $\mathrm{T} 2 \mathrm{D}$ on major adverse cardiovascular events (MACE), i.e. myocardial infarction, stroke, or CV death and microvascular endpoints, i.e. new or worsening nephropathy or retinopathy [10]. SBP was measured at six successive visits for 24 months after randomization and was used to estimate its variability, defined as SD. During a median 2.4 years of follow-up, the SD of SBP variability was associated with the incidence of both MACE and microvascular events despite multiple adjustments for a plethora of variables including mean SBP [10].

The ADVANCE-ON (ADVANCE-Observational) followed-up 9114 patients not experiencing MACE, renal events, or death during the active phase of the trial for an additional observational follow-up of 7.6 years after termination of the treatments. The SD of SBP, measured during the 24 months of active phase of the trial, was loglinearly and independently associated with an increased risk of the primary outcome, i.e. MACE, renal events, or death, during the protracted follow-up, extending the previous findings to a longer-term range [11].

A retrospective cohort study was conducted in primary care and analyzed 124,105 Chinese adults with T2D and without prior diagnosed CV disease (CVD) [12]. During a median follow-up of 39.5 months, a positive linear relationship was observed between the SBP variability and the incidence of both newly developed CVD and allcause mortality, irrespectively of the mean SBP [12]. In particular, patients with an SD of SBP of $<5 \mathrm{mmHg}$ had the lowest risks while patients with an SD of $\geq 10 \mathrm{mmHg}$ had the highest risk [12]. Another, retrospective cohort study enrolling 10,163 patients with T2D and free of CVD at baseline showed that the variability of SBP was associated with an increased risk of CVD, independently of the mean SBP level [13]. Of note, five different metrics, i.e. SD, coefficient of variation, variation independent of mean, average real variability, and successive variability of measurements, measured during 24-months of observation, were used to perform the analysis [13]. In the "The Rio de Janeiro Type 2 Diabetes Cohort Study", SBP-visit-to-visit variability emerged as an independent predictor of MACE (hazard ratio: 1.25, 95\% CI 1.03-1.51 for a 1-SD increase in 24-month SD), but not of total CV events, $\mathrm{CV}$ and all-cause mortality, and of any microvascular outcome [14].

Very recently, pooled data from the ACCORD and VADT Trials have shown that both systolic and diastolic blood pressure variability can favor the development of heart failure in T2D, an effect likely mediated by dips, not elevations, of blood pressure [15].

A post-hoc analysis pooling data from the Irbesartan Diabetic Nephropathy Trial (IDNT) and the "Reduction of End Points in Non-Insulin-Dependent Diabetes With the Angiotensin II Antagonist Losartan" (RENAAL) Study explored the effect of long-term blood pressure variability on $\mathrm{CV}$ and renal endpoints in 2739 participants with T2D and nephropathy [16]. The renal endpoint was a composite of time to confirmed doubling of serum creatinine level, development of end-stage renal disease, or death, while the CV outcome was defined as $\mathrm{CV}$ death, myocardial infarction, stroke, hospitalization for heart failure, or revascularization [16]. Larger SBP visit-to-visit variability was independently associated with an increased risk for the composite renal endpoint, but not with the CV outcome [16]. Similarly, another study taking advantage of clinical records from 30,851 T2D patients with hypertension and normal estimated glomerular filtration rate (eGFR) at baseline found that an increased long-term blood pressure variability predicted kidney disease, defined as a composite of eGFR less than 60 and/or a decrease in eGFR at least $30 \%$ from baseline levels during a 4-year follow-up [17]. Of note, SBP variability was measured by three metrics: coefficient of variation, SD of the mean SBP and average absolute difference of successive values in each individual, all providing similar results [17]. Several clinical characteristics (older age, male sex, SBP, diastolic blood pressure, albuminuria, glycated hemoglobin, insulin treatment) were related to intra-individual SBP variability [17]. More recently, the role of visit-to-visit variability of blood pressure on the development of hypertension and changes in renal function in patients with T2D diabetes and normal blood pressure has been evaluated in a real-life clinical setting [18]. After a mean follow-up time of $3.5 \pm 2.8$ years, an increase of $5 \mathrm{mmHg}$ of visit-to-visit variability of blood pressure was associated with a $19 \%$ $(\mathrm{P}<0.0001)$ and a $5 \%(\mathrm{P}=0.008)$ independent increased risk of developing hypertension and worsening of albuminuria, respectively [18].

Overall, a number of studies suggests that variability of SBP is independently associated with the development of a range of diabetes complications, while less data are 
available for diastolic blood pressure variability. The studies showing an association of blood pressure variability with diabetes complications are summarized in Table 1.

\section{Lipids}

High-density-lipoprotein-cholesterol (HDL), triglycerides, and low-density-lipoprotein-cholesterol (LDL) visit-to-visit variability has been associated with CVD in non-diabetic subjects [19].

Patients with diabetes are known to suffer from a marked variability of the lipids plasma levels [20]. More recently, in 162 T2D patients followed for 1 year, it has been shown that the LDL variability was as independent determinant of carotid maximum IMT, independently of a number of variables including mean LDL levels, body mass index (BMI), waist circumference, diabetes therapy and duration, means and SD of glycaemic and other lipid variables, as well as the use of hypolipidemic and antihypertensive drugs [21]. A more recent study correlates high LDL variability with an increased risk of CVD in T2D [22].

In another study, data from 1792 subjects who underwent percutaneous coronary intervention were analyzed [23]. During a median follow-up of 65 months, 114 patients (6.4\%) had a MACE [23]. Visit-to-visit variability in LDL-, HDL-, and non-HDL-cholesterol was significantly higher in the group suffering a $\mathrm{CV}$ event compared to those not experiencing the endpoint [23]. In the multiple regression analysis, LDL-, HDL-, and non-HDLcholesterol variability parameters were all independent predictors of $\mathrm{CV}$ events after adjusting for a number of confounding variables. These relationships were also observed in the subgroup with diabetes [23].

Of note, HDL variability has been reported as risk factor for the appearance also of albuminuria in T2D [24]. Finally, while there are no data linking visit-to-visit variability of triglycerides to macrovascular complications of diabetes, two studies show that both high levels of postprandial (i.e. short-term variability) and visit-to-visit variability of triglycerides predict the development or worsening of nephropathy in diabetes [25-27]. The main characteristics of the studies showing an association of lipids variability with diabetes complications are summarized in Table 2.

\section{Body weight}

Several years ago, the evidence that variability in body weight (BW) could be related to high risk of CVD emerged from the Framingham Study [28].

Data from three clinical trials were pooled and used to evaluate the impact of BW variability in 6408 patients with T2D on the development of macrovascular endpoints, using a composite of coronary heart disease death, myocardial infarction, resuscitated cardiac arrest, coronary revascularization, and unstable or new-onset angina as the primary endpoint [29]. When used as a time-dependent covariate, BW variability, measured as average successive variability, was linearly and independently associated with an increased risk of any coronary event, major coronary event, any $\mathrm{CV}$ event, and death. In particular, when comparing the highest with the lowest quintile of BW variability, the increased risk for any component of the composite outcome was substantially higher [29]. These results suggest that among subjects with T2D, fluctuation in BW is associated with higher mortality and a higher rate of $\mathrm{CV}$ events, independent of traditional CV risk factors [29].

The ACCORD trial participants' weight was documented annually during the trial [30].

Out of the 10,251 ACCORD participants, 911 (8.9\%) has normal weight, 2985 (29.1\%) were overweight, and 6355 (62\%) were obese. During a mean of 3.5 years of follow-up, BW variability was associated with the primary outcome MACE, but also with heart failure, death, and microvascular events, an observation independent of $\mathrm{CV}$ risk factors and BMI [30].

The "Verona Diabetes Study" explored the impact of variability of fasting glycaemia, BMI, and pulse pressure, measured as coefficient of variation, on all-cause mortality in 1319 subjects with T2D followed for 10 years [31]. When analyzing data according to age subgroups, the variability of glycaemia, BMI and pulse pressure independently predicted all-cause mortality in patients $>65$ years, but not in younger subjects, suggesting a possible role for the variability of these risk factors in determining mortality in older patients with T2D [31].

\section{Uric acid}

High level of uric acid has been reported to be a risk factor for both CVD and nephropathy in diabetes [32,33].

There are not specific studies relative to uric acid variability in relation to CVD development in patients with diabetes. However, in 8822 non-diabetic men, aged 40-65, followed for 5 years, coronary heart disease and all-cause mortality yielded a significant association with the variability of uric acid [34]. More recently, high uric acid variability has been found associated with a higher risk of developing future $\mathrm{CV}$ events in patient with coronary artery disease [35].

A recent study showed that the variability of uric acid was predictive of kidney alteration, particularly of eGRF decline, in T2D [36]. Of note, serum uric acid levels are related to insulin resistance and BMI, rather than insulin levels, suggesting that obesity-driven metabolic syndrome as a major determinant of its levels [37]. 
Table 1 Summary of the studies showing an effect of blood pressure variability on the development of complications in patients with diabetes

\begin{tabular}{|c|c|c|c|c|c|c|c|c|}
\hline Risk factor & $\begin{array}{l}\text { Type of } \\
\text { variability } \\
\text { assessed }\end{array}$ & $\begin{array}{l}\text { Short or } \\
\text { long term } \\
\text { variability }\end{array}$ & Metrics used & $\begin{array}{l}\text { Type of } \\
\text { study }\end{array}$ & Sample size & $\begin{array}{l}\text { Significantly } \\
\text { associated } \\
\text { outcomes }\end{array}$ & Follow-up length & References \\
\hline \multirow[t]{15}{*}{$\begin{array}{l}\text { Systolic blood } \\
\text { pressure }\end{array}$} & Visit-to-visit & Long-term & $\begin{array}{l}\text { Standard } \\
\text { deviation }\end{array}$ & $\begin{array}{l}\text { Post-hoc } \\
\text { analysis of } \\
\text { trial }\end{array}$ & 9114 & $\begin{array}{l}\text { MACE; micro- } \\
\text { vascular } \\
\text { outomes }\end{array}$ & 2.4 years & {$[10]$} \\
\hline & & & & $\begin{array}{l}\text { Post-hoc } \\
\text { analysis of } \\
\text { trial }\end{array}$ & 9114 & $\begin{array}{l}\text { MACE, renal } \\
\text { events, or } \\
\text { death; }\end{array}$ & 7.6 years & [11] \\
\hline & & & & $\begin{array}{l}\text { Retrospec- } \\
\text { tive cohort } \\
\text { study }\end{array}$ & 124105 & $\begin{array}{l}\text { Newly devel- } \\
\text { oped CVD; } \\
\text { all-cause } \\
\text { mortality }\end{array}$ & 39.5 months & {$[12]$} \\
\hline & & & & $\begin{array}{l}\text { Retrospec- } \\
\text { tive cohort } \\
\text { study }\end{array}$ & 10163 & Risk of CVD & 24 months & [13] \\
\hline & & & & $\begin{array}{l}\text { Prospective } \\
\text { cohort } \\
\text { study }\end{array}$ & 632 & MACE & 11.3 years & [14] \\
\hline & & & & $\begin{array}{l}\text { Post-hoc } \\
\text { analysis of } 2 \\
\text { trials }\end{array}$ & 2739 & $\begin{array}{l}\text { Composite } \\
\text { renal out- } \\
\text { come }\end{array}$ & $2.6 / 3.4$ years & {$[16]$} \\
\hline & & & & $\begin{array}{l}\text { Retrospec- } \\
\text { tive cohort } \\
\text { study }\end{array}$ & 30851 & $\begin{array}{l}\text { Composite } \\
\text { renal out- } \\
\text { come }\end{array}$ & 4 years & {$[17]$} \\
\hline & & & $\begin{array}{l}\text { Coefficient of } \\
\text { variation }\end{array}$ & $\begin{array}{l}\text { Post-hoc } \\
\text { analysis of } 2 \\
\text { trials }\end{array}$ & $\begin{array}{l}9383 \text { plus } \\
1550\end{array}$ & $\begin{array}{l}\text { Heart failure } \\
\text { develop- } \\
\text { ment }\end{array}$ & 56.6 months/59.5 months & {$[15]$} \\
\hline & & & & $\begin{array}{l}\text { Retrospec- } \\
\text { tive cohort } \\
\text { study }\end{array}$ & 10163 & Risk of CVD & 24 months & [13] \\
\hline & & & & $\begin{array}{l}\text { Retrospec- } \\
\text { tive cohort } \\
\text { study }\end{array}$ & 30851 & $\begin{array}{l}\text { Composite } \\
\text { renal out- } \\
\text { come }\end{array}$ & 4 years & {$[17]$} \\
\hline & & & $\begin{array}{l}\text { Variation } \\
\text { independ- } \\
\text { ent of mean }\end{array}$ & $\begin{array}{l}\text { Retrospec- } \\
\text { tive cohort } \\
\text { study }\end{array}$ & 10163 & Risk of CVD & 24 months & [13] \\
\hline & & & $\begin{array}{c}\text { Average real } \\
\text { variability }\end{array}$ & $\begin{array}{l}\text { Retrospec- } \\
\text { tive cohort } \\
\text { study }\end{array}$ & 10163 & risk of CVD & 24 months & [13] \\
\hline & & & & $\begin{array}{l}\text { Post-hoc } \\
\text { analysis of } 2 \\
\text { trials }\end{array}$ & $\begin{array}{l}9383 \text { plus } \\
1550\end{array}$ & $\begin{array}{l}\text { Heart failure } \\
\text { related } \\
\text { event }\end{array}$ & 56.6 months/59.5 months & {$[15]$} \\
\hline & & & & $\begin{array}{l}\text { Retrospec- } \\
\text { tive cohort } \\
\text { study }\end{array}$ & 30851 & $\begin{array}{l}\text { Composite } \\
\text { renal out- } \\
\text { come }\end{array}$ & 4 years & {$[17]$} \\
\hline & & & $\begin{array}{l}\text { Successive } \\
\text { variability of } \\
\text { measure- } \\
\text { ments }\end{array}$ & $\begin{array}{l}\text { Retrospec- } \\
\text { tive cohort } \\
\text { study }\end{array}$ & 10163 & Risk of CVD & 24 months & [13] \\
\hline $\begin{array}{l}\text { Diastolic } \\
\text { blood pres- } \\
\text { sure }\end{array}$ & Visit-to-visit & Long-term & $\begin{array}{l}\text { Coefficient } \\
\text { of variation } \\
\text { AND Aver- } \\
\text { age real } \\
\text { variability }\end{array}$ & $\begin{array}{l}\text { Post-hoc } \\
\text { analysis of } 2 \\
\text { trials }\end{array}$ & $\begin{array}{l}9383 \text { plus } \\
1550\end{array}$ & $\begin{array}{l}\text { Heart failure } \\
\text { develop- } \\
\text { ment }\end{array}$ & 56.6 months/59.5 months & {$[15]$} \\
\hline
\end{tabular}


Table 2 Summary of the studies showing an effect of lipids variability on the development of complications in patients with diabetes

\begin{tabular}{|c|c|c|c|c|c|c|c|c|}
\hline Risk factor & $\begin{array}{l}\text { Type of } \\
\text { variability } \\
\text { assessed }\end{array}$ & $\begin{array}{l}\text { Short or } \\
\text { long term } \\
\text { variability }\end{array}$ & Metrics used & Type of study & Sample size & $\begin{array}{l}\text { Significantly } \\
\text { associated } \\
\text { outcomes }\end{array}$ & $\begin{array}{l}\text { Follow-up } \\
\text { length }\end{array}$ & References \\
\hline \multirow[t]{3}{*}{ LDL } & Visit-to-visit & Long-term & $\begin{array}{l}\text { Standard devia- } \\
\text { tion }\end{array}$ & $\begin{array}{l}\text { Observational } \\
\text { cohort }\end{array}$ & 162 & $\begin{array}{l}\text { Carotid intima- } \\
\text { media thick- } \\
\text { ness }\end{array}$ & 1 year & [21] \\
\hline & & & & $\begin{array}{l}\text { Observational } \\
\text { cohort }\end{array}$ & 5354 & $\begin{array}{l}\text { Cardiovascular } \\
\text { events }\end{array}$ & 3.2 years & [22] \\
\hline & & & & $\begin{array}{l}\text { Observational } \\
\text { cohort }\end{array}$ & 1792 & $\begin{array}{l}\text { Cardiovascular } \\
\text { events }\end{array}$ & 65 months & [23] \\
\hline \multirow[t]{2}{*}{$\mathrm{HDL}$} & Visit-to-visit & Long-term & $\begin{array}{l}\text { Standard devia- } \\
\text { tion }\end{array}$ & $\begin{array}{l}\text { Observational } \\
\text { cohort }\end{array}$ & 1792 & $\begin{array}{l}\text { Cardiovascular } \\
\text { events }\end{array}$ & 65 months & [23] \\
\hline & & & & $\begin{array}{l}\text { Observational } \\
\text { cohort }\end{array}$ & 864 & $\begin{array}{c}\text { Appearance of } \\
\text { albuminuria }\end{array}$ & 3 years & {$[24]$} \\
\hline $\begin{array}{l}\text { Non-HDL cho- } \\
\text { lesterol }\end{array}$ & Visit-to-visit & Long-term & $\begin{array}{l}\text { Standard devia- } \\
\text { tion }\end{array}$ & $\begin{array}{l}\text { Observational } \\
\text { cohort }\end{array}$ & 1792 & $\begin{array}{l}\text { Cardiovascular } \\
\text { events }\end{array}$ & 65 months & [23] \\
\hline \multirow[t]{2}{*}{ Triglycerides } & Visit-to-visit & Long-term & $\begin{array}{l}\text { Standard devia- } \\
\text { tion }\end{array}$ & $\begin{array}{l}\text { Observational } \\
\text { cohort }\end{array}$ & 457 & $\begin{array}{l}\text { Incident micro- } \\
\text { albuminuria }\end{array}$ & 6.8-years & {$[27]$} \\
\hline & Post-prandial & Short-term & $\begin{array}{l}\text { Coefficient of } \\
\text { variation }\end{array}$ & $\begin{array}{l}\text { Observational } \\
\text { cohort }\end{array}$ & 168 & eGFR decline & 6.0 years & {$[26]$} \\
\hline
\end{tabular}

\section{Heart rate}

Differently from the other discussed risk factors, heart rate (HR) variability is often studied by a resting ECG or with a 24-h Holter, thus it refers to short-term variability and not to visit-to-visit variability. In particular, low-frequency $(0.04-0.15 \mathrm{~Hz})$ oscillations are a surrogate measure of HR variability ascribable to both sympathetic and parasympathetic innervation [38-41]. Cardiac autonomic neuropathy affects the parasympathetic nervous system, leading to reduced HR variability [38]. In people without diabetes, decreased HR variability is associated with an increased incidence of cardiac events [39].

Low HR variability has been reported in both type [1] (T1D) and T2D and, intriguingly, in pre-diabetes [40].

A preliminary study explored the impact of autonomic neuropathy on HR variability and on the progression of atherosclerosis in 61 T2D patients followed for 8 years [41]. Results suggested that patients with autonomic neuropathy had decreased low frequency HR variability, which was correlated with both a reduced carotid artery diameter and an increased atherosclerotic intima-media thickness (IMT). HR variability further decreased during follow-up, while patients with lower frequency of HR at baseline had a more relevant enlargement in the thickness of the carotid bulb intima-media at follow-up, possibly suggesting that a low frequency $H R$ variability might foresee the degree of atherosclerosis progression in patients with T2D [41].

Subjects with T1D or those without diabetes from the "Coronary Artery Calcification in Type 1 Diabetes" study underwent supine deep breathing 12-lead electrocardiograms [42]. The SD of consecutive RR intervals was used as a measure of HR variability. Coronary artery calcium was measured at two visits 6 years apart. Reduced HR variability was associated in both T1D and healthy controls with older age, higher $\mathrm{HbA1c}$, elevated albuminuria, coronary artery calcium volume, as well as higher fibrinogen levels at baseline. Higher HR variability at baseline was independently associated with a decreased probability of coronary artery calcium progression, even after adjusting for a range of $\mathrm{CV}$ risk factors including inflammatory parameters [42].

Finally, two studies, both with a follow-up of about 5 years, were able to show that low HR variability is related to a high risk of cardiac and total mortality in T2D [43, 44]. The main characteristics of the studies showing an association between body weight, uric acid, and heart variability and diabetes complications are summarized in Table 3.

\section{Interaction between the variability of the risk factors}

It is well known that there is a cumulative effect of the various risk factors in producing serious $\mathrm{CV}$ complications. This evidence originally came out from the historical Framingham Heart Study [45]. In the same study it was also clear that the presence of diabetes contributes to amplify the additive effect of the risk factors in the development of the CV complications [45].

As above reported, the variability of a risk factor contributes an additive risk, independently from the magnitude and the duration of the abnormal level of 


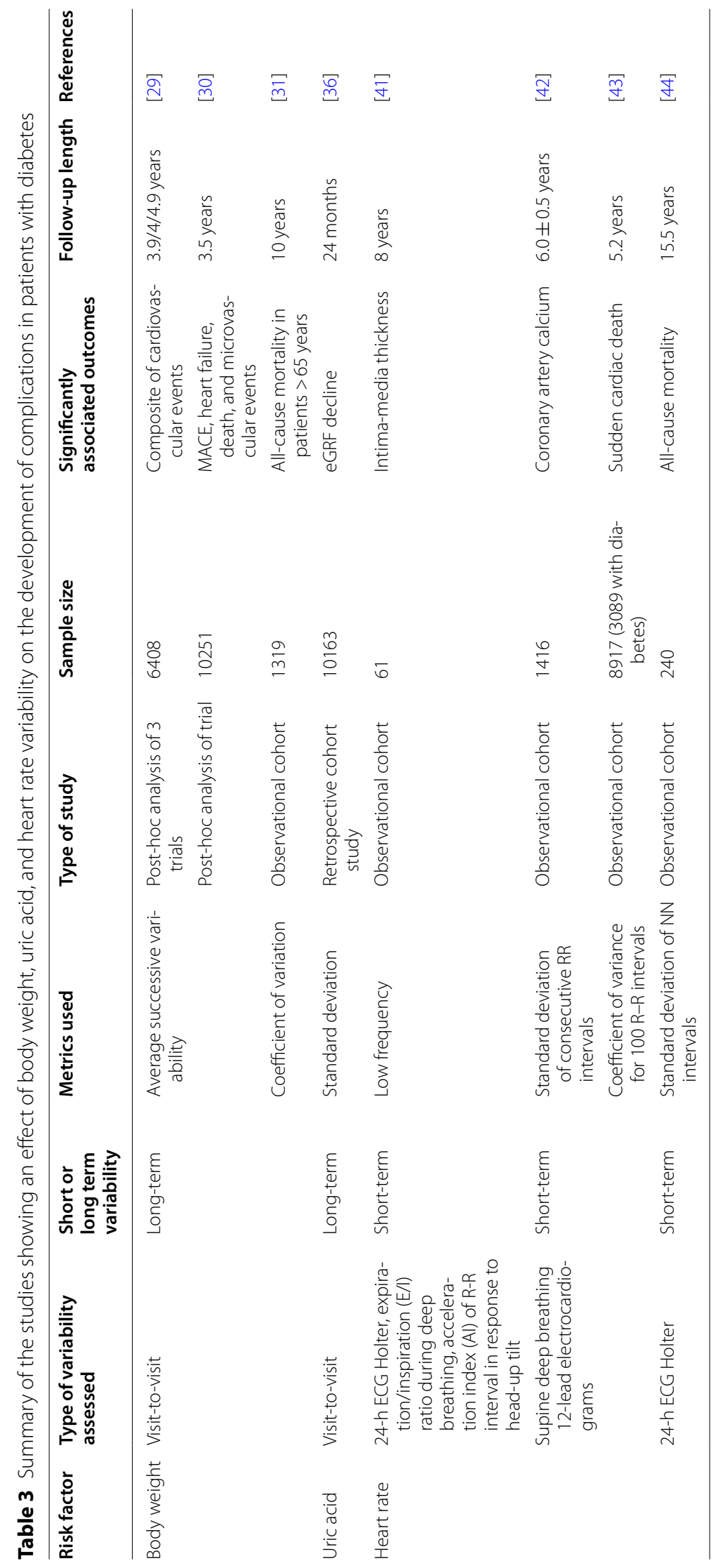


the risk factor. The research in this field is relatively new, however, some evidence already exists. Studies have explored the effect of the simultaneous variability of several risk factors on a target complication. In non-diabetic subjects the combined variability of several risk factors contributes to the risk for both CVD and end stage renal disease $[46,47]$. An additive effect of $\mathrm{HbA} 1 \mathrm{c}$ and blood pressure variability on the risk of mortality has been reported in T1D patients followedup for 1430 days [48]. The hazard ratio for high HbA1c variability was $1.78 \pm 0.36$. The hazard ratio for high SBP variability was $1.69 \pm 0.33$. The hazard ratio for high HbA1c and high SBP variability together was $2.37 \pm 0.32$ [48]. In older T2D patients the variability of fasting glycaemia, BW and blood pressure were independently associated with an increased risk of allcause mortality during the 10 years of follow-up [31]. In people with T2D an inverse association has been reported between glucose fluctuations and heart rate variability [49]. Another study reported that glucose and blood pressure variability were associated with endothelial and CV damage in diabetic patients with optimal metabolic control [50]. However, in a population of patients with T2D and no history of CVD, in which other CV risk factors were within or near to the recommended targets, only 2 -h post breakfast blood glucose level, but not the variability of blood pressure, lipids and creatinine, was associated with incident CVD, as observed during the follow-up period of $5-8$ years [51].

In T2D the additive effect of HbA1c, fasting glucose, systolic and diastolic blood pressure, total-cholesterol, HDL, LDL, triglycerides, and uric acid variability on the appearance of kidney disease has been reported [36].

A recent study using data from a clinical database reporting at least 5 measures of multiple risk factors from 4231 patients with T2D followed up for a median of 3.4 years showed that a significantly higher risk of developing albuminuria was associated with variability in HbA1c, while the variability in systolic and diastolic blood pressure, HDL, LDL and uric acid predicted the decline in eGFR, with the association with uric acid variability being particularly strong [36]. In addition, the concomitance of high variability in $\mathrm{HbAlc}$ and HDL conferred the highest risk of developing albuminuria (Fig. 1), while a high variability in uric acid or diastolic blood pressure conferred the highest risk of decline in eGFR (Fig. 2). This novel evidence suggests that the contribution of the variability of each single factor might have higher or lesser impact according to the specific complication studied [36]. This new field of research needs more studies.

\section{Is it time to treat?}

The major issue is whether risk factors variability is causal or a marker, and, while with glucose the case for causality can be made [1], it would be more difficult with uric acid, for example.

The evidence in favour to be just a marker is that the overall quality of care seems conditioning the variability of all these risk factors [52]. The quality-of-care summary score (Q-score) is a surrogate, validated measure of quality of care as a whole. The frequency of risk factors measurement, their values, and the relative pharmacological therapy contribute to produce the Q-score, the values of which can range between zero and forty with higher scores being descriptive of better quality of care [52]. In a study including 273,888 people with diabetes the variability of $\mathrm{HbA1c}$, systolic and diastolic blood pressure, total cholesterol, LDL, HDL, and uric acid was inversely correlated with the Q-score value [52]. In a multivariate linear regression analysis a Q-score $>25$ was associated with a significantly minor variation in HbA1c, systolic and diastolic blood pressure, uric acid, total cholesterol, HDL, and LDL cholesterol, when compared to a score $<15$ [52]. The analysis of standardized $\beta$ coefficients evidenced that the Q-score had a higher impact on the variability of $\mathrm{HbA}_{1 \mathrm{c}}$, SBP, total cholesterol, and LDL cholesterol [52]. This finding suggests that when a quality-of-care improvement is pursued to increase the achievement of the recommended targets, this action might be accompanied by a reduction of risk factors variability. This seems to be the case. In a recent study, the attainment of HbA1c, blood pressure, and LDL-cholesterol goals was associated with a significant improvement of their variability [53].

However, it also true that, according to Hill definition of causality, the variability of several risk factors does fit with this concept [54]. Indeed, the findings relative to the association with the quality of care intuitively suggest that risk factors variability might result from clinical inertia and drug non-adherence, two pervasive phenomena in real-world settings of diabetes treatment [55]. Therefore, more studies are needed to explore both the relevance of these two phenomena in determining variability and to assess if variability of risk factors per se represents an additive driver of diabetes complications.

The current strategy for the management of a risk factor is to try to maintain its levels within the normal range as long as possible. The evidence that the variability in time of a risk factor has a potential harmful effect on the development of diabetic complications opens the discussion of whether a new therapeutic strategy is needed: the normalization of the level of a risk factor might be not enough without reducing its variability. Whether it seems more than acceptable to improve the quality of care and to reach the optimal target, hoping that these actions 


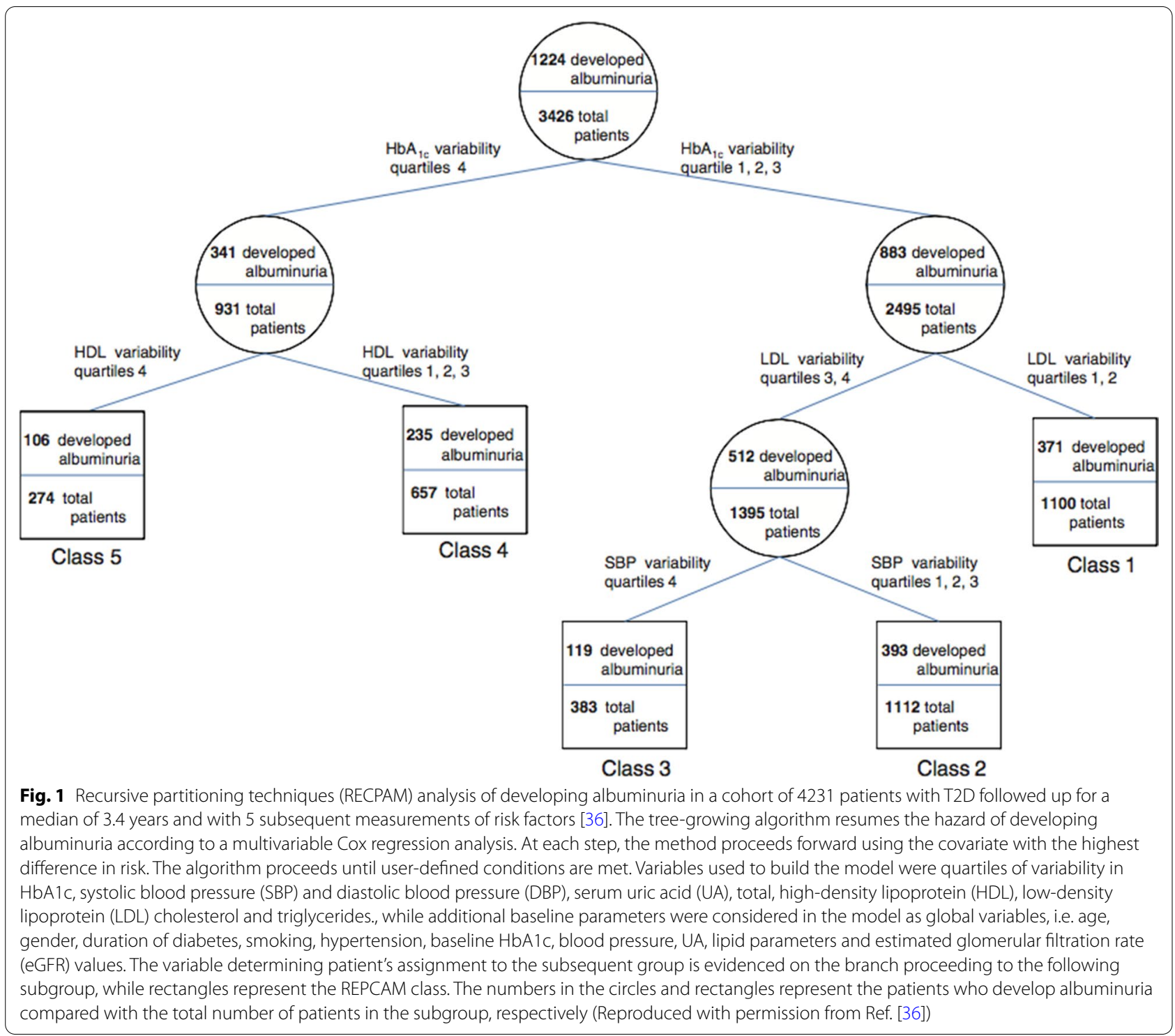

may also improve the variability of the risk factors [52, 53], the key issue is whether it is also the case to plan more specific interventions to improve the variability of a risk factor. This seems, for example, the case for glucose variability [56].

The question is certainly not only a scientific curiosity. There is also the possibility of intervening on the variability of a specific risk factor.

Diverse anti-hypertensive drugs have different effects on reducing blood pressure variability. Indeed, a metaanalysis suggested that variability of SBP was decreased by calcium-channel blockers and thiazides, while it was increased by angiotensin-converting enzyme inhibitors, angiotensin-receptor blockers, and beta-blockers [57]. Similarly, the use of a SGLT-2 inhibitor may also be helpful in reducing not only blood pressure but also its variability [58].

Although statin therapy is widely known to substantially decrease LDL, variability in LDL levels during the treatment has been observed. Although visit-to-visit variability in LDL is largely attributable to statin nonadherence, it is worthy to remember that Bangalore et al. showed that LDL variability was consistently less pronounced with the atorvastatin dose of $80 \mathrm{mg} /$ day compared to the $10 \mathrm{mg} /$ day dose $[59,60]$.

Moderate weight loss has been preliminary reported to improve HR variability in T2D [61]. Finally, weight loss strategies that minimize weight cycling probably should be given preference over those that are prone to cause a "yoyo effect" [62]. 


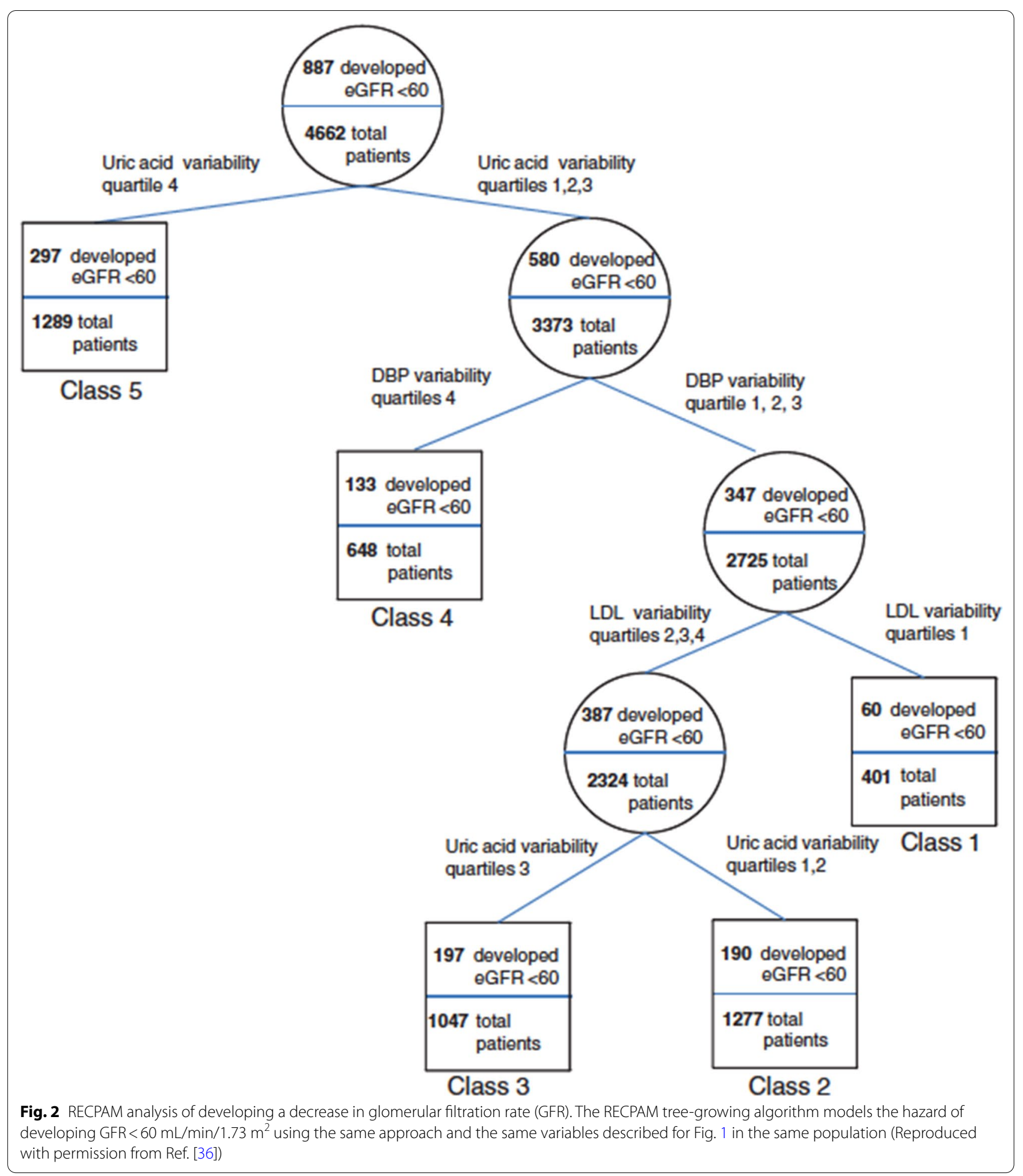

\section{Conclusions}

In most of the intervention studies in settings of T2D, a reduction in the magnitude of diverse $\mathrm{CV}$ risk factors have translated into tangible benefits on hard endpoints.
On the other side, no trial has clearly proven that a reduction in variability per se, independently of the risk factor magnitude, is beneficial. However, evidence is growing suggesting that the variability of a risk factor might be 
not less dangerous than its magnitude and/or the time spent having it in an abnormal level. Moreover, it is also enough clear that the variability of each factor is additive in leading to the final picture of a diabetic complication. Therefore, from a therapeutic viewpoint, is it time to try to reduce both magnitude and variability of $\mathrm{CV}$ risk factors? Because an improvement of the quality of care [52] and the attainment of their target [53] seem to be the best strategy to reach this goal, we believe that the answer is not complicated.

\section{Acknowledgements}

Not applicable.

\section{Authors' contributions}

AC: writing-original draft preparation; FP: writing-review and editing. Both authors read and approved the final manuscript.

\section{Funding}

This work has been supported by the Italian Ministry of Health-Ricerca Corrente to IRCCS MultiMedica and by Ricerca Finalizzata RF-2016-02364513 to $A C$.

\section{Availability of data and materials}

Not applicable.

\section{Declarations}

Ethics approval and consent to participate

Not applicable.

\section{Consent for publication}

Not applicable.

\section{Competing interests}

Authors do not have conflicts of interest to declare.

Received: 16 March 2021 Accepted: 27 April 2021

Published online: 07 May 2021

\section{References}

1. Ceriello A, Monnier L, Owens D. Glycaemic variability in diabetes: clinical and therapeutic implications. Lancet Diabetes Endocrinol. 2019;7:221-30.

2. Ranjan AG, Rosenlund SV, Hansen TW, Rossing P, Andersen S, Nørgaard K. Improved time in range over 1 year is associated with reduced albuminuria in individuals with sensor-augmented insulin pump-treated type 1 diabetes. Diabetes Care. 2020:43(11):2882-5.

3. Hirakawa Y, et al. Impact of visit-to-visit glycemic variability on the risks of macrovascular and microvascular events and all-cause mortality in type 2 diabetes: the ADVANCE trial. Diabetes Care. 2014;37:2359-65.

4. Zinman B, et al. Day-to-day fasting glycaemic variability in DEVOTE: associations with severe hypoglycaemia and cardiovascular outcomes (DEVOTE 2). Diabetologia. 2018;61:48-57.

5. Zhou JJ, Schwenke DC, Bahn G, Reaven P, VADT Investigators. Glycemic variation and cardiovascular risk in the Veterans Affairs Diabetes Trial. Diabetes Care. 2018;41:2187-94

6. Echouffo-Tcheugui JB, Zhao S, Brock G, Matsouaka RA, Kline D, Joseph JJ. Visit-to-visit glycemic variability and risks of cardiovascular events and all-cause mortality: the ALLHAT study. Diabetes Care. 2019;42:486-93.

7. Sheng CS, et al. Prognostic significance of long-term $\mathrm{HbA1}$ c variability for all-cause mortality in the ACCORD trial. Diabetes Care. 2020;43:1185-90.

8. Ceriello A, Ofstad AP, Zwiener I, Kaspers S, George J, Nicolucci A. Empagliflozin reduced long-term $\mathrm{HbA} 1 \mathrm{c}$ variability and cardiovascular death: insights from the EMPA-REG OUTCOME trial. Cardiovasc Diabetol. 2020;19:176.
9. Grove JS, Reed DM, Yano K, Hwang LJ. Variability in systolic blood pressure: a risk factor for coronary heart disease? Am J Epidemiol. 1997;145:771-6.

10. Hata J, ADVANCE Collaborative Group, et al. Effects of visit-to-visit variability in systolic blood pressure on macrovascular and microvascular complications in patients with type 2 diabetes mellitus: the ADVANCE trial. Circulation. 2013;128:1325-34.

11. Ohkuma T, ADVANCE Collaborative Group, et al. Prognostic value of variability in systolic blood pressure related to vascular events and premature death in type 2 diabetes mellitus: the ADVANCE-ON study. Hypertension. 2017;70:461-8.

12. Wan EY, Fung CS, Yu EY, Fong DY, Chen JY, Lam CL. Association of visitto-visit variability of systolic blood pressure with cardiovascular disease and mortality in primary care Chinese patients with type 2 diabetes: a retrospective population-based cohort study. Diabetes Care. 2017;40:270-9.

13. Yu ZB, et al. Association of visit-to-visit variability of blood pressure with cardiovascular disease among type 2 diabetes mellitus patients: a cohort study. Diabetes Metab J. 2019:43:350-67.

14. Cardoso CRL, Leite NC, Salles GF. Prognostic importance of visit-to-visit blood pressure variability for micro- and macrovascular outcomes in patients with type 2 diabetes: the Rio de Janeiro type 2 diabetes cohort study. Cardiovasc Diabetol. 2020;19:50.

15. Nuyujukian DS, Koska J, Bahn G, Reaven PD, Zhou JJ, VADT Investigators. Blood pressure variability and risk of heart failure in ACCORD and the VADT. Diabetes Care. 2020;43:1471-8.

16. McMullan CJ, Lambers Heerspink HJ, Parving HH, Dwyer JP, Forman JP, de Zeeuw D. Visit-to-visit variability in blood pressure and kidney and cardiovascular outcomes in patients with type 2 diabetes and nephropathy: a post hoc analysis from the RENAAL study and the Irbesartan diabetic nephropathy trial. Am J Kidney Dis. 2014;64:714-22.

17. Viazzi F, AMD-Annals Study Group, et al. Long-term blood pressure variability and development of chronic kidney disease in type 2 diabetes. J Hypertens. 2019;37:805-13.

18. Viazzi F, AMD-Annals Study Group, et al. Long-term blood pressure variability, incidence of hypertension and changes in renal function in type 2 diabetes. J Hypertens. 2020;38:2279-86.

19. Waters DD, et al. Visit-to-visit variability of lipid measurements as predictors of cardiovascular events. J Clin Lipidol. 2018;12:356-66.

20. Hulse $M$, Gershberg $H$. Variability in blood cholesterol, triglycerides, free fatty acids, glucose and body weight in maturity-onset diabetics. Am J Med Sci. 1969;258:114-20.

21. Takenouchi A, et al. Visit-to-visit low-density lipoprotein cholesterol variability is an independent determinant of carotid intima-media thickness in patients with type 2 diabetes. J Clin Med Res. 2017;9:310-6.

22. Hsu WH, et al. Greater low-density lipoprotein cholesterol variability increases the risk of cardiovascular events in patients with type 2 diabetes mellitus. Endocr Pract. 2019;25:918-25.

23. Lee EY, et al. Effect of visit-to-visit LDL-, HDL-, and non-HDL-cholesterol variability on mortality and cardiovascular outcomes after percutaneous coronary intervention. Atherosclerosis. 2018;279:1-9.

24. Chang YH, Chang DM, Lin KC, Hsieh CH, Lee YJ. High-density lipo-protein cholesterol and the risk of nephropathy in type 2 diabetic patients. Nutr Metab Cardiovasc Dis. 2013;23:751-7.

25. Ceriello A, Genovese S. Atherogenicity of postprandial hyperglycemia and lipotoxicity. Rev Endocr Metab Disord. 2016;17:111-6.

26. Tsuboi A, Takenouchi A, Kurata M, Fukuo K, Kazumi T. Postmeal triglyceridemia and variability of $\mathrm{HbA} 1 \mathrm{c}$ and postmeal glycemia were predictors of annual decline in estimated glomerular filtration rate in type 2 diabetic patients with different stages of nephropathy. J Diabetes Metab Disord. 2017;16:1.

27. Bardini G, Innocenti M, Rotella CM, Giannini S, Mannucci E. Variability of triglyceride levels and incidence of microalbuminuria in type 2 diabetes. J Clin Lipidol. 2016;10:109-15.

28. Lissner L, et al. Variability of body weight and health outcomes in the Framingham population. N Engl J Med. 1991;324:1839-44.

29. Bangalore S, Fayyad R, DeMicco DA, Colhoun HM, Waters DD. Body weight variability and cardiovascular outcomes in patients with type 2 diabetes mellitus. Circ Cardiovasc Qual Outcomes. 2018;11:e004724.

30. Yeboah P, Hsu FC, Bertoni AG, Yeboah J. Body Mass Index, change in weight, body weight variability and outcomes in type 2 diabetes mellitus (from the ACCORD trial). Am J Cardiol. 2019;123:576-81. 
31. Zoppini G, Verlato G, Targher G, Bonora E, Trombetta M, Muggeo M. Variability of body weight, pulse pressure and glycaemia strongly predict total mortality in elderly type 2 diabetic patients. The Verona diabetes study. Diabetes Metab Res Rev. 2008;24:624-8.

32. Viazzi F, et al. Natural history and risk factors for diabetic kidney disease in patients with T2D: lessons from the AMD-annals. J Nephrol. 2019;32:517-25.

33. Verma S. Association between uric acid levels and cardio-renal outcomes and death in patients with type 2 diabetes: a subanalysis of EMPA-REG OUTCOME. Diabetes Obes Metab. 2020;22:1207-14.

34. Grossman C, Grossman E, Goldbourt U. Uric acid variability at midlife as an independent predictor of coronary heart disease and all-cause mortality. PLoS ONE. 2019;14:e0220532.

35. Lim SS, et al. Association of variability in uric acid and future clinical outcomes of patient with coronary artery disease undergoing percutaneous coronary intervention. Atherosclerosis. 2020;297:40-6.

36. Ceriello A, AMD-Annals Study Group, et al. Variability in $\mathrm{HbA1c}$, blood pressure, lipid parameters and serum uric acid, and risk of development of chronic kidney disease in type 2 diabetes. Diabetes Obes Metab. 2017;19:1570-8

37. Bonora E, et al. Relationship of uric acid concentration to cardiovascular risk factors in young men. Role of obesity and central fat distribution. The Verona young men atherosclerosis risk factors study. Int J Obes Relat Metab Disord. 1996;20(11):975-80.

38. Proceedings of a consensus development conference on standardized measures in diabetic neuropathy. Summary and recommendations. Diabetes Care 1992;15:1104-1107.

39. Tsuji $\mathrm{H}$, et al. Impact of reduced heart rate variability on risk for cardiac events: the Framingham heart study. Circulation. 1996;94:2850-5.

40. Coopmans $C$, et al. Both prediabetes and type 2 diabetes are associated with lower heart rate variability: the Maastricht study. Diabetes Care. 2020;43:1126-33.

41. Gottsäter A, Ahlgren AR, Taimour S, Sundkvist G. Decreased heart rate variability may predict the progression of carotid atherosclerosis in type 2 diabetes. Clin Auton Res. 2006;16:228-34.

42. Rodrigues TC, Ehrlich J, Hunter CM, Kinney GL, Rewers M, Snell-Bergeon $J K$. Reduced heart rate variability predicts progression of coronary artery calcification in adults with type 1 diabetes and controls without diabetes. Diabetes Technol Ther. 2010;12:963-9.

43. Kataoka M, Ito C, Sasaki H, Yamane K, Kohno N. Low heart rate variability is a risk factor for sudden cardiac death in type 2 diabetes. Diabetes Res Clin Pract. 2004;64:51-8.

44. May $\mathrm{O}$, Arildsen $\mathrm{H}$. Long-term predictive power of heart rate variability on all-cause mortality in the diabetic population. Acta Diabetol. 2011;48:55-9.

45. Mahmood SS, Levy D, Vasan RS, Wang TJ. The Framingham heart study and the epidemiology of cardiovascular disease: a historical perspective. Lancet. 2014;383:999-1008.

46. Kim MK, et al. Associations of variability in blood pressure, glucose and cholesterol concentrations, and body mass index with mortality and cardiovascular outcomes in the general population. Circulation. 2018;138:2627-3263.

47. Kim MK, et al. Effects of variability in blood pressure, glucose, and cholesterol concentrations, and body mass index on end-stage renal disease in the general population of Korea. J Clin Med. 2019:8:755.
48. Wightman SS, Sainsbury CAR, Jones GC. Visit-to-visit HbA1c variability and systolic blood pressure (SBP) variability are significantly and additively associated with mortality in individuals with type 1 diabetes: an observational study. Diabetes Obes Metab. 2018;20:1014-7.

49. Chen Y, Jia T, Yan X, Dai L. Blood glucose fluctuations in patients with coronary heart disease and diabetes mellitus correlates with heart rate variability: a retrospective analysis of 210 cases. Niger J Clin Pract. 2020;23:1194-200.

50. Di Flaviani A, et al. Impact of glycemic and blood pressure variability on surrogate measures of cardiovascular outcomes in type 2 diabetic patients. Diabetes Care. 2011;34:1605-9.

51. Hashemi Madani N, Ismail-Beigi F, Khamseh ME, Malek M, Ebrahimi Valojerdi A. Predictive and explanatory factors of cardiovascular disease in people with adequately controlled type 2 diabetes. Eur J Prev Cardiol. 2017;24:1181-9.

52. Ceriello A, AMD-Annals Study Group, et al. Overall quality of care predicts the variability of key risk factors for complications in type 2 diabetes: an observational, longitudinal retrospective study. Diabetes Care. 2019;42:514-9.

53. Kitaoka K, et al. Association of $A B C(H b A 1 c$, blood pressure and LDLcholesterol) goal achievement with visit-to-visit $A B C$ variability and postprandial dysmetabolism in type 2 diabetic patients. Asia Pac J Clin Nutr. 2020;29:476-82

54. Hill AB. The environment and disease: association or causation? 1965. J R Soc Med. 2015;108:32-7.

55. Reach G, Pechtner V, Gentilella R, Corcos A, Ceriello A. Clinical inertia and its impact on treatment intensification in people with type 2 diabetes mellitus. Diabetes Metab. 2017;43(6):501-11.

56. Ceriello A. Glucose variability and diabetic complications: is it time to treat? Diabetes Care. 2020;43:1169-71.

57. Webb AJ, Fischer U, Mehta Z, Rothwell PM. Effects of antihypertensivedrug class on interindividual variation in blood pressure and risk of stroke: a systematic review and meta-analysis. Lancet. 2010;375:906-15.

58. Kario K, Ferdinand KC, O'Keefe JH. Control of 24-hour blood pressure with SGLT2 inhibitors to prevent cardiovascular disease. Prog Cardiovasc Dis. 2020;63:249-62.

59. Mann DM, et al. A pilot study identifying statin nonadherence with visitto-visit variability of low-density lipoprotein cholesterol. Am J Cardiol. 2013;15:1437-42.

60. Bangalore $S$, et al. Relation of variability of low-density lipoprotein cholesterol and blood pressure to events in patients with previous myocardial infarction from the IDEAL trial. Am J Cardiol. 2017;119:379-87.

61. Sjoberg N, Brinkworth GD, Wycherley TP, Noakes M, Saint DA. Moderate weight loss improves heart rate variability in overweight and obese adults with type 2 diabetes. J Appl Physiol. 2011;110:1060-4.

62. Contreras RE, Schriever SC, Pfluger PT. Physiological and epigenetic features of yoyo dieting and weight control. Front Genet. 2019;10:1015.

\section{Publisher's Note}

Springer Nature remains neutral with regard to jurisdictional claims in published maps and institutional affiliations.

Ready to submit your research? Choose BMC and benefit from:

- fast, convenient online submission

- thorough peer review by experienced researchers in your field

- rapid publication on acceptance

- support for research data, including large and complex data types

- gold Open Access which fosters wider collaboration and increased citations

- maximum visibility for your research: over 100M website views per year

At BMC, research is always in progress.

Learn more biomedcentral.com/submissions 